\title{
Evaluasi Kesesuaian Data Satelit untuk Curah Hujan dan Evaporasi Terhadap Data Pengukuran di Kawasan Waduk Sutami
}

\author{
Naufal Achmad Arrokhman ${ }^{1 *}$, Sri Wahyuni ${ }^{1}$, Ery Suhartanto ${ }^{1}$ \\ ${ }^{1}$ Jurusan Teknik Pengairan, Fakultas Teknik, Universitas Brawijaya, Jalan MT. \\ Haryono No. 167, Malang, 65145, INDONESIA \\ *Korespondensi Email: naufalachmad@ student.ub.ac.id
}

\begin{abstract}
Sutami Reservoir is a multipurpose reservoir, so it is necessary to record complete rainfall data and evaporation data as a basis for regulating reservoir operation patterns, water balance analysis, and others. Satellite technology can be applied as such an alternative to hydrological data to anticipate incompleteness and inaccuracy of data during observation.. This study aimed to evaluate satellite data of rainfall and evaporation with observation data in the Sutami Reservoir Area. TRMM 3B42, CHIRPS, and GPM V6 are used by rainfall satellite. And then, GLDAS-2.1 and CFS-V2 are used by evaporation satellite. Each of these satellites has different specifications and characteristics. Evaluation of satellite data was carried out using simulation model calibration and validation to determine the performance of the satellite. The best results can be known from the values of RMSE, NSE, Correlation Efficiency, and Relative Error. The results show that in essence, all rainfall satellites (TRMM 3B42, CHIRPS, GPM V6) and evaporation satellites (GLDAS-2.1, CFS-V2) can be used as an alternative to hydrological data in the Sutami Reservoir Area. The GPM V6 rainfall satellite and the CFS-V2 evaporation satellite have a higher level of accuracy and better performance based on calibration and validation simulations.
\end{abstract}

Keywords: calibration, evaporation, rainfall, satellite data, validation

Abstrak: Waduk Sutami merupakan waduk multiguna sehingga diperlukan pencatatan data curah hujan maupun data evaporasi yang lengkap sebagai dasar mengatur pola operasi waduk, analisis neraca air, dan lain-lain. Seiring perkembangan zaman, teknologi satelit dapat digunakan sebagai alternatif data hidrologi untuk mengantisipasi ketidaklengkapan dan ketidak-akuratan data saat pengukuran. Tujuan dari penelitian ini untuk melakukan evaluasi data satelit curah hujan dan evaporasi terhadap data pengukuran di Kawasan Waduk Sutami. Dari penelitian ini juga akan menghasilkan satelit yang direkomendasikan untuk dapat diterapkan pada lokasi studi. Dalam penelitian ini, penulis menggunakan data satelit curah hujan TRMM 3B42, CHIRPS, dan GPM V6. Sedangkan satelit evaporasi menggunakan GLDAS-2.1 dan CFS-V2. Masing-masing satelit tersebut mempunyai spesifikasi dan karakteristik yang berbeda-beda. Evaluasi data satelit dilakukan dengan menggunakan simulasi model kalibrasi dan validasi untuk mengetahui performa dari satelit tersebut. Hasil yang terbaik dapat diketahui dari nilai RMSE, NSE, Koefisien Korelasi, dan Kesalahan Relatif. Hasil penelitian menunjukkan bahwa pada intinya, seluruh satelit curah hujan

*Penulis korespendensi: naufalachmad@student.ub.ac.id 
(TRMM 3B42, CHIRPS, GPM V6) maupun satelit evaporasi (GLDAS-2.1, CFSV2) dapat digunakan sebagai alternatif data hidrologi di Kawasan Waduk Sutami. Hanya saja satelit curah hujan GPM V6 dan satelit evaporasi CFS-V2 memiliki tingkat keakurasian yang lebih tinggi dan performa yang lebih baik berdasarkan simulasi kalibrasi dan validasi.

Kata Kunci: curah hujan, data satelit, evaporasi, kalibrasi, validasi

\section{Pendahuluan}

Siklus hidrologi meliputi presipitasi, evaporasi, infiltrasi, limpasan permukaan dan air tanah. Intensitas dan frekuensi siklus hidrologi bergantung pada geografi dan iklim [1]. Ketersediaan air yang ada di waduk dapat dipengaruhi oleh curah hujan dan evaporasi. Besarnya curah hujan akan mempengaruhi debit yang masuk ke dalam waduk. Sedangkan evaporasi menjadi faktor penentu besarnya kehilangan air yang terjadi di waduk.

Waduk Sutami merupakan waduk multiguna yang berfungsi sebagai penyedia air baku, irigasi, pengendali banjir, pembangkit listrik, kegiatan perikanan, dan kegiatan pariwisata. Oleh karena itu, diperlukan pencatatan data curah hujan maupun data evaporasi yang lengkap sebagai dasar mengatur pola operasi waduk, analisis neraca air, dan lain-lain.

Pencatatan curah hujan dapat diketahui dari pos stasiun hujan dengan menggunakan alat penakar hujan manual (Manual raingauge) ataupun alat penakar hujan otomatis (Automatic raingauge) dalam satuan milimeter $(\mathrm{mm})$. Sedangkan pencatatan evaporasi dapat diperoleh dari stasiun klimatologi dengan menggunakan alat panci penguapan (evaporation pan) dalam satuan milimeter $(\mathrm{mm})$.

Seiring dengan perkembangan zaman, teknologi satelit dapat digunakan sebagai alternatif data hidrologi untuk mengantisipasi ketidaklengkapan dan ketidak-akuratan data saat pengukuran. Dalam penelitian ini, penulis menggunakan data satelit untuk curah hujan dan evaporasi. Satelit curah hujan menggunakan Tropical Rainfall Measurement Mission (TRMM) 3B42, Climate Hazards Group InfraRed Precipitation with Station (CHIRPS), dan Global Precipitation Measurement (GPM) V6. Sedangkan satelit evaporasi menggunakan Global Land Data Assimilation System (GLDAS) 2.1 dan Climate Forecast System (CFS) V2. Masing-masing satelit tersebut mempunyai spesifikasi yang berbedabeda dari segi resolusi spasial, ketersediaan data, tempo perekaman data, dan satuan data.

Tujuan dari studi ini adalah untuk melakukan evaluasi data satelit curah hujan dan evaporasi terhadap data pengukuran di Kawasan Waduk Sutami. Dari penelitian ini juga akan menghasilkan satelit yang direkomendasikan untuk dapat diterapkan pada lokasi studi. Evaluasi perlu dilakukan karena satelit mengukur besarnya hujan yang terjadi di atmosfer, sedangkan data hujan pengamatan dari stasiun hujan adalah data hujan yang terjadi di lapangan atau bumi [2]. Evaluasi data satelit dilakukan dengan menggunakan simulasi model kalibrasi dan validasi untuk mengetahui performa dari satelit tersebut. Hasil yang terbaik dapat diketahui dari nilai Root Mean Squared Error (RMSE), Nash Sutcliffe Efficiency (NSE), Koefisien Korelasi (R), dan Kesalahan Relatif (KR).

Sebelumnya telah dilakukan penelitian mengenai data satelit dengan berbagai metode, seperti penelitian dari Faisol yang membandingkan data satelit Climate Hazards Group Infrared Precipitation With Stations (CHIRPS) dengan Global Precipitation Measurement (GPM) di wilayah Jawa Timur menggunakan beberapa parameter statistika seperti Mean 
error, Relative bias, Mean bias factor, Percent bias, dan Pearson coefisient [3]. Penelitian juga dilakukan oleh Syaifullah pada DAS Sutami-Brantas dengan membandingkan data TRMM NASA (3B42RT) dengan TRMM Jaxa (GSMap_NRT) menggunakan metode korelasi [4]. Pratiwi dalam penelitiannya melakukan evaluasi terhadap data satelit TRMM 3B42, TRMM 3B42RT, GPM dan PERSIANN CCS menggunakan metode Cross Correlation [2]. Mulyandari juga melakukan evaluasi terhadap data satelit TRMM dan PERSIANN untuk digunakan dalam analisis debit banjir rancangan [5]. Serta Ginting telah melakukan perbandingan data satelit GPM dan PERSIANN dengan metode koefisien korelasi dan perhitungan waktu lag dengan hasil bahwa satelit GPM memiliki keakuratan yang lebih tinggi [6].

\section{Bahan dan Metode}

\subsection{Bahan}

\subsubsection{Lokasi Studi}

Lokasi studi yang dipilih adalah kawasan Waduk Sutami atau disebut juga Waduk Karangkates. Waduk ini terletak di Desa Karangkates, Kecamatan Sumberpucung, Kabupaten Malang, Provinsi Jawa Timur yang terletak pada koordinat $08^{\circ} 09^{\prime} 23,24^{\prime \prime}-08^{\circ}$ $12^{\prime} 24,83^{\prime \prime}$ LS dan $112^{\circ} 26^{\prime} 45,42^{\prime \prime}$ - $112^{\circ} 32^{\prime}$ 59,26" BT. Pada penelitian ini untuk pengambilan data pengukuran curah hujan di kawasan Waduk Sutami menggunakan 7 (tujuh) stasiun hujan yaitu Stasiun Geofisika Karangkates, Sumberpucung, Kepanjen, Karangsuko, Gondanglegi, Pagak, dan Kalipare. Sedangkan untuk pengambilan data pengukuran evaporasi menggunakan 1 (satu) lokasi yaitu di Stasiun Geofisika Karangkates.

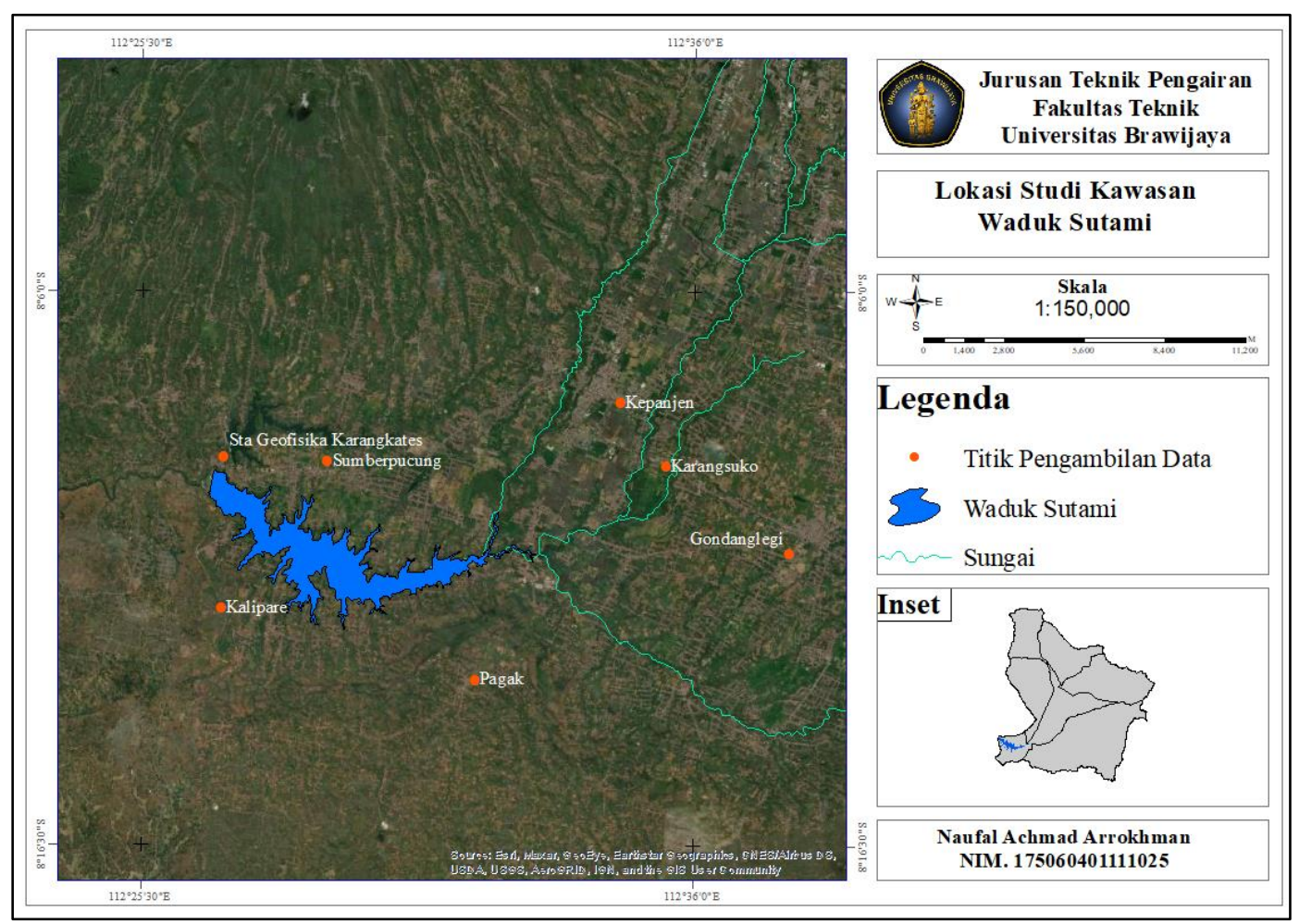

Gambar 1: Lokasi studi 


\subsubsection{Data Penelitian}

Dalam studi ini menggunakan data sekunder sebagai berikut:

- Data pengukuran curah hujan Stasiun Geofisika Karangkates, Sumberpucung, Kepanjen, Karangsuko, Gondanglegi, Pagak, dan Kalipare dari tahun 2001-2019 yang diperoleh dari Dinas PU Sumber Daya Air Kabupaten Malang.

- Data pengukuran evaporasi Stasiun Geofisika Karangkates dari tahun 2001-2019 yang diperoleh dari Stasiun Geofisika Karangkates.

- Data satelit curah hujan TRMM 3B42, CHIRPS, dan GPM V6 dari tahun 2001-2019. Data satelit curah hujan dapat diunduh melalui platform Google Earth Engine (GEE) dengan website https://earthengine.google.com/.

- Data satelit evaporasi GLDAS-2.1 dan CFS-V2 dari tahun 2001-2019. Data satelit evaporasi dapat diunduh melalui platform Google Earth Engine (GEE) dengan website https://earthengine.google.com/.

- Koordinat lokasi pengambilan data curah hujan dan evaporasi. Data ini diperoleh dari Dinas PU Sumber Daya Air Kabupaten Malang.

Alat bantu yang digunakan dalam studi ini antara lain:

- Perangkat lunak Microsoft Excel sebagai alat utama dalam analisis pehitungan meliputi uji konsistensi, uji stasioner, kalibrasi, dan validasi data.

- Perangkat lunak ArcGIS 10.4 untuk mengolah visualisasi data satelit yang diunduh dari platform Google Earth Engine (GEE).

\subsubsection{Spesifikasi Satelit}

Masing-masing satelit mempunyai spesifikasi yang berbeda-beda dari segi resolusi spasial, ketersediaan data, tempo perekaman data, dan satuan data. Spesifikasi satelit disajikan pada Tabel 1 sebagai berikut:

Tabel 1: Spesifikasi satelit

\begin{tabular}{ccccc}
\hline Satelit & $\begin{array}{c}\text { Resolusi } \\
\text { Spasial }\end{array}$ & Ketersediaan Data* & $\begin{array}{c}\text { Tempo } \\
\text { Perekaman }\end{array}$ & Satuan \\
\hline \hline TRMM 3B42 & $0,25^{0}$ & 1 Jan 1998 - 31 Des 2019 & 3 jam & $\mathrm{mm} / \mathrm{jam}$ \\
CHIRPS & $0,05^{0}$ & 1 Jan 1981 - 31 Mei 2021 & 1 hari & $\mathrm{mm} / \mathrm{hari}$ \\
GPM V6 & $0,10^{0}$ & 1 Jun 2000 - 18 Jun 2021 & 30 menit & $\mathrm{mm} / \mathrm{jam}$ \\
GLDAS-2.1 & $0,25^{0}$ & 1 Jan 2000 - 13 Mei 2021 & 3 jam & $\mathrm{W} / \mathrm{m}^{2}$ \\
CFS-V2 & $0,20^{0}$ & 1 Jan 1979 - 19 Juni 2021 & 6 jam & $\mathrm{W} / \mathrm{m}^{2}$ \\
\hline
\end{tabular}

Keterangan:

*Data selalu mengalami pembaharuan

\subsection{Metode}

Pada tahap pengumpulan data, khusus untuk data evaporasi perlu dilakukan konversi untuk menjadi evaporasi waduk. Studi diawali dengan uji kualitas data terhadap data curah hujan dan evaporasi baik data pengukuran maupun satelit. Uji kualitas data tersebut terdiri dari uji konsistensi dan uji stasioner (uji-F dan uji-t). Uji konsistensi untuk menguji kebenaran data yang tidak dipengaruhi kesalahan saat pengukuran. Sedangkan uji stasioner untuk melihat kestabilan nilai varian (uji-F) dan kestabilan nilai rata-rata (uji-t).

Selanjutnya adalah melakukan simulasi model kalibrasi dan validasi dengan pembagian tahun terdapat pada Tabel 2. Tahap kalibrasi menggunakan analisis regresi 
dengan scatter plot. Pada tahap ini dapat diketahui hubungan data pengukuran dengan data satelit. Sedangkan pada tahap validasi menguji keakurasian dari model kalibrasi menggunakan parameter Root Mean Squared Error (RMSE), Nash Sutcliffe Efficiency (NSE), Koefisien Korelasi (R), dan Kesalahan Relatif (KR).

Tahap validasi dibagi menjadi validasi belum terkoreksi dan validasi terkoreksi. Pada tahap validasi terkoreksi diperoleh jenis persamaan regresi terpilih akhir yang dapat digunakan untuk mengoreksi data satelit sebelum digunakan. Hasil terbaik dari parameter nilai validasi dapat digunakan untuk menentukan rekomendasi satelit curah hujan dan evaporasi untuk lokasi studi Kawasan Wasuk Sutami.

Tabel 2: Simulasi model kalibrasi dan validasi

\begin{tabular}{c|cc|cc|}
\hline Simulasi & \multicolumn{2}{|c|}{ Kalibrasi } & \multicolumn{2}{c|}{ Validasi } \\
\hline \hline I & 16 tahun & $2001-2016$ & 3 tahun & $2017-2019$ \\
II & 17 tahun & $2001-2017$ & 2 tahun & $2018-2019$ \\
III & 18 tahun & $2001-2018$ & 1 tahun & 2019 \\
\hline
\end{tabular}

Tabel 2 menjelaskan bahwa terdapat 3 (tiga) simulasi yang digunakan dalam model kalibrasi dan validasi dengan rentang data yang berbeda-beda. Masing-masing simulasi dilakukan untuk mengetahui performa dari data satelit. Persamaan regresi yang diperoleh dari tahap kalibrasi akan divalidasi untuk mengetahui jenis persamaan regresi terpilih akhir.

\subsection{Persamaan}

\subsubsection{Evaporasi Waduk}

Data pengukuran evaporasi diperoleh dari pan evaporasi Stasiun Geofisika Karangkates. Untuk menjadi evaporasi waduk perlu adanya pengalian dengan koefisien panci sebesar 0,7 [7]. Sedangkan untuk data satelit evaporasi dianggap sebagai data evaporasi potensial sehingga, perlu dikalikan dengan koefisien sebesar 0,5 [8].

$$
\mathrm{E}_{\text {waduk }}=\mathrm{k} . \mathrm{Ep} \quad \text { Pers. 1 }
$$

Keterangan:

$\mathrm{k} \quad=$ Koefisien

Ep $\quad=$ Evaporasi potensial

\subsubsection{Uji Konsistensi}

Uji konsistensi berarti menguji kebenaran data lapangan yang tidak dipengaruhi oleh kesalahan pada saat pengiriman atau saat pengukuran, data tersebut harus betul-betul menggambarkan fenomena hidrologi seperti keadaan sebenarnya. Dengan kata lain data hidrologi disebut tidak konsisten apabila terdapat perbedaan antara nilai pengukuran dan nilai sebenarnya [9]. Pada studi ini menggunakan uji konsistensi kurva masa ganda dan Rescaled Adjusted Partial Sums (RAPS).

$$
\begin{array}{lll}
\text { Sk }^{*} & =(\mathrm{Yi}-\overline{\mathrm{Y}})[\text { untuk tahun pertama] } & \text { Pers. 2 } \\
\text { Sk }^{*}=(\mathrm{Yi}-\overline{\mathrm{Y}})_{\mathrm{t}}+(\mathrm{Yi}-\overline{\mathrm{Y}})_{\mathrm{t}+1} & \text { Pers. 3 } \\
\text { Dy }^{2}=\frac{\left(\mathrm{Y}_{\mathrm{i}}-\overline{\mathrm{Y}}\right)^{2}}{\mathrm{n}} & \text { Pers. 4 } \\
\text { Dy }=\sqrt{\sum_{\mathrm{i}=1}^{\mathrm{N}} \text { Dy }^{2}} & \text { Pers. 5 }
\end{array}
$$




$$
\begin{array}{rlr}
\mathrm{Sk} * * & =\frac{\mathrm{Sk} *}{\mathrm{Dy}} & \text { Pers. } 6 \\
\mathrm{Q} & =\mid \mathrm{Sk} * * \text { maks } \mid & \text { Pers. 7 } \\
\mathrm{R} & =\mathrm{Sk}^{* *} \text { maks }-\mathrm{Sk}^{* *} \text { min } & \text { Pers. 8 }
\end{array}
$$

Keterangan:

$$
\begin{array}{ll}
\mathrm{n} & =\text { Banyak data } \\
\overline{\mathrm{Y}} & =\text { Nilai rata-rata } \\
\mathrm{Y}_{\mathrm{i}} & =\text { Data ke- } \mathrm{i}
\end{array}
$$

\subsubsection{Uji Stasioner}

Uji stasioner dimaksudkan untuk menguji kestabilan nilai varian dan rata-rata dari suatu deret berkala dan untuk mengetahui homogen atau tidaknya nilai varian dan rataratanya [9]. Uji kestabilan nilai varian menggunakan Uji-F, sedangkan uji kestabilan nilai rata-rata menggunakan uji-t.

$$
\begin{aligned}
& \mathrm{F}=\frac{N_{1} S_{1}{ }^{2}\left(N_{2}-1\right)}{N_{2} S_{2}{ }^{2}\left(N_{1}-1\right)} \\
& \sigma=\left|\frac{N_{1} S_{1}{ }^{2}+N_{2} S_{2}{ }^{2}}{N_{1}+N_{2}-2}\right|^{0.5} \\
& \mathrm{t}=\frac{\overline{X_{1}}-\overline{X_{2}}}{\sigma\left|\frac{1}{N_{1}}+\frac{1}{N_{2}}\right|^{0.5}}
\end{aligned}
$$

Pers. 9

Pers. 10

Pers. 11

Keterangan:

$\mathrm{N}_{1} \quad$ = Banyak data kelompok sampel ke-1

$\mathrm{N}_{2} \quad$ = Banyak data kelompok sampel ke-2

$\mathrm{S}_{1} \quad=$ Standar deviasi kelompok sampel ke-1

$\mathrm{S}_{2} \quad=$ Standar deviasi kelompok sampel ke-2

$\overline{X_{1}} \quad=$ Rata-rata hitung kelompok sampel ke-1

$\overline{X_{2}} \quad=$ Rata-rata hitung kelompok sampel ke-2

\subsubsection{Kalibrasi}

Kalibrasi (calibration) terhadap satu model adalah proses pemilihan kombinasi parameter. Dengan kata lain, proses optimalisasi nilai parameter untuk meningkatkan koherensi antara respon hidrologi DAS yang teramati dan tersimulasi. Metode kalibrasi yang banyak digunakan untuk pemodelan hidrologi berupa metode coba-coba dengan alasan proses perhitungan yang relatif sederhana [10]. Suatu analisis yang membahas hubungan dua variabel atau lebih disebut dengan analisis regresi. Alternatif analisis regresi yang umum digunakan dalam analisis data hidrologi diantaranya adalah model regresi [9]:

- $\quad$ Linier Sederhana

$$
\hat{\mathrm{Y}}=\mathrm{a}_{1} \mathrm{X}+\mathrm{b}_{1} \quad \text { Pers. } 12
$$

- Fungsi Eksponensial

$$
\hat{\mathrm{Y}}=b \mathrm{e}^{\mathrm{ax}}
$$

- $\quad$ Fungsi Logaritma

$$
\hat{\mathrm{Y}}=\mathrm{b}+\mathrm{a} \log \mathrm{X}
$$

Pers. 14

- Fungsi Polinomial

$$
\hat{Y}=b_{o}+b_{1} X+b_{2} X^{2}+b_{3} X^{3}+\ldots+b_{m} X^{m} \quad \text { Pers. } 15
$$


- $\quad$ Fungsi Berpangkat

$$
\hat{\mathrm{Y}}=\mathrm{b} \mathrm{X}^{\mathrm{a}}
$$

Pers. 16

Keterangan:

$\hat{\mathrm{Y}} \quad=$ Regresi $\mathrm{Y}$ terhadap $\mathrm{X}$

$\mathrm{X} \quad$ = Variabel bebas

$\mathrm{a}, \mathrm{b} \quad=$ Parameter

\subsubsection{Validasi}

Validasi (validation) adalah proses evaluasi terhadap model untuk mendapatkan gambaran tentang tingkat ketidakpastian yang dimiliki oleh suatu model dalam memprediksi proses hidrologi. Pada umumnya, validasi dilakukan dengan menggunakan data diluar periode data yang digunakan untuk kalibrasi [10]. Berikut beberapa metode validasi yang digunakan dalam studi ini:

- $\quad$ Root Mean Squared Error (RMSE)

$$
\mathrm{RMSE}=\sqrt{\frac{\sum_{i=1}^{N}\left(P_{i}-Q_{i}\right)^{2}}{N}}
$$

Pers. 17

- Nash-Sutcliffe Efficiency (NSE)

Metode ini menunjukkan seberapa baik plot nilai pengamatan (pengukuran) dibandingkan dengan nilai prediksi-simulasi menurut plot garis 1: 1, dengan rentang nilai hingga 1. Dengan kata lain, jika nilai mendekati 1, maka NSE semakin baik [11].

$$
\mathrm{NSE}=1-\frac{\sum_{i=1}^{N}\left(P_{1}-Q_{i}\right)^{2}}{\sum_{i=1}^{N}\left(P_{1}-\bar{P}_{i}\right)^{2}} \quad \text { Pers. } 18
$$

Tabel 3: Interpretasi nilai nash-sutcliffe efficiency (NSE)

\begin{tabular}{cc}
\hline Nilai NSE & Interpretasi \\
\hline \hline NSE $>0,75$ & Baik \\
$0,36<\mathrm{NSE}<0,75$ & Memenuhi \\
NSE $<0,36$ & Tidak Memenuhi \\
\hline
\end{tabular}

- $\quad$ Koefisien Korelasi (R)

Tujuan dari analisis ini adalah untuk mendapatkan pola dan kedekatan hubungan antara dua atau lebih variabel [11].

$$
\mathrm{R}=\frac{N \sum_{i=1}^{N} P_{i} Q_{i}-\sum_{i=1}^{N} P_{i} x \sum_{i=1}^{N} Q_{i}}{\sqrt{N \sum_{i=1}^{N} P_{i}{ }^{2}-\left(\sum_{i=1}^{N} P_{i}\right)^{2}} \sqrt{N \sum_{i=1}^{N} Q_{i}{ }^{2}-\left(\sum_{i=1}^{N} Q_{i}\right)^{2}}} \text { Pers. } 19
$$

Tabel 4: Interpretasi nilai koefisien korelasi (R)

\begin{tabular}{cc}
\hline Nilai R & Interpretasi \\
\hline \hline $0-0,19$ & Sangat Rendah \\
$0,20-0,39$ & Rendah \\
$0,49-0,59$ & Sedang \\
$0,60-0,79$ & Kuat \\
$0,80-1$ & Sangat Kuat \\
\hline
\end{tabular}


- $\quad$ Kesalahan Relatif (KR)

$$
\mathrm{KR}=\frac{\sum_{i=1}^{N}\left(P_{i}-Q_{i}\right)}{\sum_{i=1}^{N} P_{i}} \times 100 \%
$$

Pers. 20

Keterangan:

$$
\begin{array}{ll}
\mathrm{Pi} & =\text { Data pengukuran } \\
\mathrm{Qi} & =\text { Data satelit } \\
\mathrm{N} & =\text { Banyak data }
\end{array}
$$

\section{Hasil dan Pembahasan}

\subsection{Uji Kualitas Data}

Pada studi ini, uji kualitas data menggunakan uji konsistensi dan stasioner. Uji kualitas data dilakukan pada data curah hujan dan evaporasi waduk dari data pengukuran maupun satelit tahun 2001-2019. Pada uji konsistensi dan stasioner keseluruhan data bersifat konsisten dan stabil pada derajat kepercayaan $5 \%$.

Tabel 5: Uji kualitas data

\begin{tabular}{ccccc}
\hline \multirow{2}{*}{ Data } & \multicolumn{2}{c}{ Uji Konsistensi } & \multicolumn{2}{c}{ Uji Stasioner } \\
\cline { 2 - 5 } & Kurva Masa Ganda & RAPS & Uji-F & Uji-t \\
\hline \hline St. Geofisika & Konsisten & - & Stabil & Stabil \\
St. Sumberpucung & Konsisten & - & Stabil & Stabil \\
St. Kepanjen & Konsisten & - & Stabil & Stabil \\
St. Karangsuko & Konsisten & - & Stabil & Stabil \\
St. Gondanglegi & Konsisten & - & Stabil & Stabil \\
St. Pagak & Konsisten & - & Stabil & Stabil \\
St. Kalipare & Konsisten & - & Stabil & Stabil \\
TRMM 3B42 & - & Konsisten & Stabil & Stabil \\
CHIRPS & - & Konsisten & Stabil & Stabil \\
GPM V6 & - & Konsisten & Stabil & Stabil \\
Evaporasi pengukuran & - & Konsisten & Stabil & Stabil \\
GLDAS-2.1 & - & Konsisten & Stabil & Stabil \\
CFS-V2 & - & Konsisten & Stabil & Stabil \\
\hline
\end{tabular}

Tabel 5 merupakan hasil uji kualitas data berupa uji konsistensi dan uji stasioner. Seluruh data menunjukkan hasil yang konsisten untuk uji konsistensi dan stabil untuk uji stasioner. Dengan demikian, data dapat digunakan dalam analisis selanjutnya.

\subsection{Kalibrasi}

Kalibrasi data satelit menggunakan analisis regresi dengan bantuan perangkat lunak Microsoft Excel. Microsoft Excel mampu menyajikan 5 (lima) jenis persamaan regresi diantaranya persamaan linier, eksponensial, logaritma, polinomial, dan power (berpangkat). Data satelit curah hujan dan evaporasi dikoreksi dengan kelima persamaan tersebut untuk menentukan jenis persamaan regresi yang terbaik berdasarkan parameter koefisien korelasi terbesar (R). Data satelit sebagai variabel bebas diletakkan pada sumbu $\mathrm{X}$ sedangkan data pengukuran sebagai variabel tetap diletakkan pada sumbu Y. Kalibrasi dilakukan pada data periode bulanan dengan rentang 16 tahun, 17 tahun, dan 18 tahun. 
Dari hasil kalibrasi diperoleh untuk persamaan regresi terpilih pada satelit curah hujan TRMM 3B42, CHIRPS, dan GPM V6 di seluruh stasiun hujan didominasi oleh polinomial. Sedangkan pada satelit evaporasi GLDAS-2.1 dan CFS-V2 menunjukkan persamaan eksponensial.

\subsection{Validasi}

Validasi data satelit terkoreksi dilakukan untuk melihat tingkat keakurasian model kalibrasi menggunakan paramater Root Mean Squared Error (RMSE), Nash-Sutcliffe Efficiency (NSE), Koefisien Korelasi (R), dan Kesalahan Relatif (KR). Validasi dilakukan pada data periode bulanan dengan rentang 3 tahun, 2 tahun, dan 1 tahun. Persamaan regresi terpilih dari tahap kalibrasi dilakukan validasi pada tahun di luar kalibrasi. Nilai RMSE dan KR terbaik adalah yang paling mendekati angka nol, sedangkan nilai NSE dan R terbaik adalah yang paling mendekati angka 1 .

Dari hasil validasi diperoleh bahwa TRMM 3B42 memiliki nilai RMSE minimum sebesar 45,419 di Stasiun Kepanjen pada rentang data 2 tahun. Nilai NSE maksimum sebesar 0,858 dengan interpretasi "Baik" di Stasiun Kepanjen pada rentang data 2 tahun. Nilai R maksimum sebesar 0,931 dengan interpretasi "Sangat Kuat" di Stasiun Karangsuko pada rentang data 3 tahun. Nilai KR minimum sebesar 0,724\% di Stasiun Kepanjen pada rentang data 2 tahun.

CHIRPS memiliki nilai RMSE minimum sebesar 49,785 di Stasiun Gondanglegi pada rentang data 1 tahun. Nilai NSE maksimum sebesar 0,864 dengan interpretasi "Baik" di Stasiun Gondanglegi pada rentang data 1 tahun. Nilai R maksimum sebesar 0,958 dengan interpretasi "Sangat Kuat" di Stasiun Gondanglegi pada rentang data 1 tahun. Nilai KR minimum sebesar 0,464\% di Stasiun Kepanjen pada rentang data 3 tahun.

GPM V6 memiliki nilai RMSE minimum sebesar 48,281 di Stasiun Kepanjen pada rentang data 2 tahun. Nilai NSE maksimum sebesar 0,869 dengan interpretasi "Baik" di Stasiun Geofisika pada rentang data 2 tahun. Nilai R maksimum sebesar 0,944 dengan interpretasi "Sangat Kuat" di Stasiun Geofisika pada rentang data 1 tahun. Nilai KR minimum sebesar $0,677 \%$ di Stasiun Geofisika pada rentang data 2 tahun.

GLDAS-2.1 memiliki nilai RMSE minimum sebesar 9,187 pada rentang data 3 tahun. Nilai NSE maksimum sebesar 0,684 dengan interpretasi "Memenuhi" pada rentang data 2 tahun. Nilai R maksimum sebesar 0,844 dengan interpretasi "Sangat Kuat" pada rentang data 2 tahun. Nilai KR minimum sebesar $0,842 \%$ pada rentang data 1 tahun.

CFS-V2 memiliki nilai RMSE minimum sebesar 4,976 pada rentang data 1 tahun. Nilai NSE maksimum sebesar 0,909 dengan interpretasi "Baik" pada rentang data 1 tahun. Nilai $\mathrm{R}$ maksimum sebesar 0,968 dengan interpretasi "Sangat Kuat" pada rentang data 1 tahun. Nilai KR minimum sebesar $1,174 \%$ pada rentang data 1 tahun.

Tabel 6: Perbandingan nilai validasi belum terkoreksi (BT) dan terkoreksi (T)

\begin{tabular}{ccc|cc|cc|cc}
\hline \multirow{2}{*}{ Satelit } & \multicolumn{2}{c|}{ RMSE } & \multicolumn{2}{c|}{ NSE } & \multicolumn{3}{c|}{ R } & \multicolumn{2}{c}{ KR (\%) } \\
\cline { 2 - 9 } & BT & T & BT & T & BT & T & BT & T \\
\hline \hline TRMM 3B42 & 55,759 & 45,419 & 0,851 & 0,858 & 0,927 & 0,931 & 0,033 & 0,724 \\
CHIRPS & 49,844 & 49,785 & 0,864 & 0,864 & 0,944 & 0,958 & 1,090 & 0,464 \\
GPM V6 & 59,358 & 48,281 & 0,847 & 0,869 & 0,936 & 0,944 & 1,133 & 0,677 \\
GLDAS-2.1 & 28,395 & 9,187 & $-1,949$ & 0,684 & 0,838 & 0,844 & 26,910 & 0,842 \\
CFS-V2 & 90,861 & 4,976 & $-31,257$ & 0,909 & 0,963 & 0,968 & 98,042 & 1,174 \\
\hline
\end{tabular}


Tabel 6 merupakan nilai validasi data satelit belum terkoreksi dengan terkoreksi berdasarkan parameter Root Mean Squared Error (RMSE), Nash-Sutcliffe Efficiency (NSE), Koefisien Korelasi (R), dan Kesalahan Relatif (KR). Hasil validasi terkoreksi cenderung lebih baik daripada validasi belum terkoreksi. Hal ini dikarenakan data terkoreksi sudah melalui koreksi data pada tahap kalibrasi.

\subsection{Pemilihan Rekomendasi Satelit}

Dari hasil validasi data satelit curah hujan TRMM 3B42, CHIRPS, GPM V6 dan data satelit evaporasi GLDAS-2.1 dan CFS-V2 pada pembahasan sebelumnya dapat ditentukan satelit yang direkomendasikan. Pada studi ini penentuan rekomendasi satelit menggunakan parameter nilai Nash-Sutcliffe Efficiency (NSE) dan Koefisien Korelasi (R) terbaik pada setiap model kalibrasi validasi yang disajikan pada Tabel 7 untuk satelit curah hujan dan Tabel 8 untuk satelit evaporasi.

Tabel 7: Penentuan rekomendasi satelit curah hujan

\begin{tabular}{|c|c|c|c|c|c|c|c|c|}
\hline \multirow{2}{*}{ Stasiun } & \multicolumn{2}{|c|}{ TRMM 3B42 } & \multicolumn{2}{|c|}{ CHIRPS } & \multicolumn{2}{|c|}{ GPM V6 } & \multicolumn{2}{|c|}{ Hasil Terbaik } \\
\hline & NSE & $\mathrm{R}$ & NSE & $\mathrm{R}$ & NSE & $\mathrm{R}$ & NSE & $\mathrm{R}$ \\
\hline \multirow{3}{*}{ Geofisika } & 0,795 & 0,894 & 0,675 & 0,842 & 0,837 & 0,923 & GPM V6 & GPM V6 \\
\hline & 0,820 & 0,908 & 0,809 & 0,901 & 0,869 & 0,939 & GPM V6 & GPM V6 \\
\hline & 0,762 & 0,890 & 0,770 & 0,891 & 0,804 & 0,944 & GPM V6 & GPM V6 \\
\hline \multirow{3}{*}{ Sumberpucung } & 0,662 & 0,887 & 0,595 & 0,801 & 0,602 & 0,889 & TRMM 3B42 & GPM V6 \\
\hline & 0,762 & 0,926 & 0,757 & 0,899 & 0,743 & 0,925 & TRMM 3B42 & TRMM 3B42 \\
\hline & 0,434 & 0,903 & 0,403 & 0,907 & 0,388 & 0,910 & TRMM 3B42 & GPM V6 \\
\hline \multirow{3}{*}{ Kepanjen } & 0,811 & 0,905 & 0,761 & 0,872 & 0,778 & 0,901 & TRMM 3B42 & TRMM 3B42 \\
\hline & 0,858 & 0,928 & 0,760 & 0,884 & 0,839 & 0,932 & TRMM 3B42 & GPM V6 \\
\hline & 0,263 & 0,728 & $-0,160$ & 0,205 & 0,326 & 0,885 & GPM V6 & GPM V6 \\
\hline \multirow{3}{*}{ Karangsuko } & 0,786 & 0,931 & 0,748 & 0,882 & 0,727 & 0,889 & TRMM 3B42 & TRMM 3B42 \\
\hline & 0,791 & 0,907 & 0,782 & 0,899 & 0,766 & 0,896 & TRMM 3B42 & TRMM 3B42 \\
\hline & 0,610 & 0,828 & 0,712 & 0,884 & 0,678 & 0,854 & CHIRPS & CHIRPS \\
\hline \multirow{3}{*}{ Gondanglegi } & 0,836 & 0,924 & 0,814 & 0,911 & 0,793 & 0,916 & TRMM 3B42 & TRMM 3B42 \\
\hline & 0,819 & 0,924 & 0,836 & 0,938 & 0,799 & 0,920 & CHIRPS & CHIRPS \\
\hline & 0,694 & 0,859 & 0,864 & 0,958 & 0,827 & 0,913 & CHIRPS & CHIRPS \\
\hline \multirow{3}{*}{ Pagak } & 0,706 & 0,856 & 0,773 & 0,881 & 0,683 & 0,883 & CHIRPS & GPM V6 \\
\hline & 0,700 & 0,847 & 0,811 & 0,914 & 0,706 & 0,875 & CHIRPS & CHIRPS \\
\hline & 0,507 & 0,765 & 0,571 & 0,821 & 0,524 & 0,841 & CHIRPS & GPM V6 \\
\hline \multirow{3}{*}{ Kalipare } & 0,549 & 0,746 & 0,546 & 0,746 & 0,612 & 0,803 & GPM V6 & GPM V6 \\
\hline & 0,373 & 0,636 & 0,521 & 0,728 & 0,563 & 0,759 & GPM V6 & GPM V6 \\
\hline & $-0,709$ & 0,007 & $-0,496$ & 0,177 & $-0,260$ & 0,057 & GPM V6 & CHIRPS \\
\hline
\end{tabular}

Tabel 8: Penentuan rekomendasi satelit evaporasi

\begin{tabular}{c|cc|cc|cc}
\hline \multirow{2}{*}{ Stasiun } & \multicolumn{2}{|c|}{ GLDAS-2.1 } & \multicolumn{2}{c|}{ CFS-V2 } & \multicolumn{2}{c}{ Hasil Terbaik } \\
\cline { 2 - 7 } & NSE & R & NSE & R & NSE & R \\
\hline \multirow{3}{*}{ Geofisika } & 0,670 & 0,836 & 0,705 & 0,893 & CFS-V2 & CFS-V2 \\
& 0,684 & 0,844 & 0,710 & 0,889 & CFS-V2 & CFS-V2 \\
& 0,637 & 0,801 & 0,909 & 0,968 & CFS-V2 & CFS-V2 \\
\hline
\end{tabular}

Pada Tabel 7 dapat diketahui bahwa TRMM 3B42 memiliki hasil validasi terbaik sebanyak 31\%, CHIRPS sebanyak 26\%, dan GPM V6 sebanyak 43\%. Pada Tabel 8 diketahui bahwa CFS-V2 memiliki hasil validasi terbaik 100\%. Berdasaran parameter tersebut maka, satelit curah hujan GPM V6 dan satelit evaporasi CFS-V2 merupakan satelit yang direkomendasikan untuk digunakan pada lokasi studi Kawasan Waduk Sutami. 


\subsection{Pemilihan Model Kalibrasi dan Validasi}

Studi ini menggunakan 3 (tiga) simulasi model kalibrasi dan validasi. Nilai yang dihasilkan antar simulasi tentu berbeda. Hal ini dapat dipengaruhi oleh jumlah dan karakteristik data. Pada Tabel 9 disajikan model kalibrasi validasi terbaik dari satelit GPM V6 dan CFS-V2 berdasarkan nilai Nash-Sutcliffe Efficiency (NSE) tertinggi.

Tabel 9: Pemilihan model kalibrasi dan validasi

\begin{tabular}{ccccccc}
\hline \multirow{2}{*}{ Satelit } & \multirow{2}{*}{ Stasiun } & \multirow{2}{*}{ Periode } & \multicolumn{2}{c}{ Model Terbaik } & & \multirow{2}{*}{ Persamaan Regresi } \\
& & & Kalibrasi & Validasi & & \\
\hline \hline \multirow{4}{*}{ GPM V6 } & Geofisika & Bulanan & 17 tahun & 2 tahun & Polinomial & $\mathrm{y}=0,0002 \mathrm{x}^{2}+0,7015 \mathrm{x}$ \\
& Kepanjen & Bulanan & 17 tahun & 2 tahun & Polinomial & $\mathrm{y}=-4 \mathrm{E}-05 \mathrm{x}^{2}+0,788 \mathrm{x}$ \\
& Karangsuko & Bulanan & 17 tahun & 2 tahun & Polinomial & $\mathrm{y}=-0,0002 \mathrm{x}^{2}+0,8886 \mathrm{x}$ \\
& Gondanglegi & Bulanan & 18 tahun & 1 tahun & Polinomial & $\mathrm{y}=6 \mathrm{E}-06 \mathrm{x}^{2}+0,8051 \mathrm{x}$ \\
& Pagak & Bulanan & 17 tahun & 2 tahun & Polinomial & $\mathrm{y}=0,0002 \mathrm{x}^{2}+0,8119 \mathrm{x}$ \\
& Kalipare & Bulanan & 16 tahun & 3 tahun & Polinomial & $\mathrm{y}=0,0003 \mathrm{x}^{2}+0,7306 \mathrm{x}$ \\
\hline \multirow{2}{*}{ CFS-V2 } & Geofisika & Bulanan & 18 tahun & 1 tahun & Eksponensial & $\mathrm{y}=50,332 \mathrm{e}^{0,0032 \mathrm{x}}$ \\
\hline
\end{tabular}

Berdasarkan Tabel 9 dapat diketahui model terbaik beserta persamaan regresi tiap stasiun. Model terbaik ditentukan berdasarkan nilai parameter Nash-Sutcliffe Efficiency (NSE) tertinggi pada masing-masing stasiun. Stasiun Geofisika, Sumberpucung, Kepanjen, Karangsuko, dan Pagak menunjukkan model terbaik 17 tahun kalibrasi 2 tahun validasi. Stasiun Gondanglegi menunjukkan model terbaik 18 tahun kalibrasi 1 tahun validasi. Sedangkan Stasiun Kalipare menunjukkan model terbaik 16 tahun kalibrasi 3 tahun validasi. Persamaan tersebut dapat digunakan untuk mengoreksi data satelit curah hujan GPM V6 dan satelit evaporasi CFS-V2 dengan periode bulanan. Pada satelit GPM V6 menggunakan persamaan polinomial untuk seluruh stasiun hujan, sedangkan satelit CFS V2 menggunakan persamaan eksponensial.

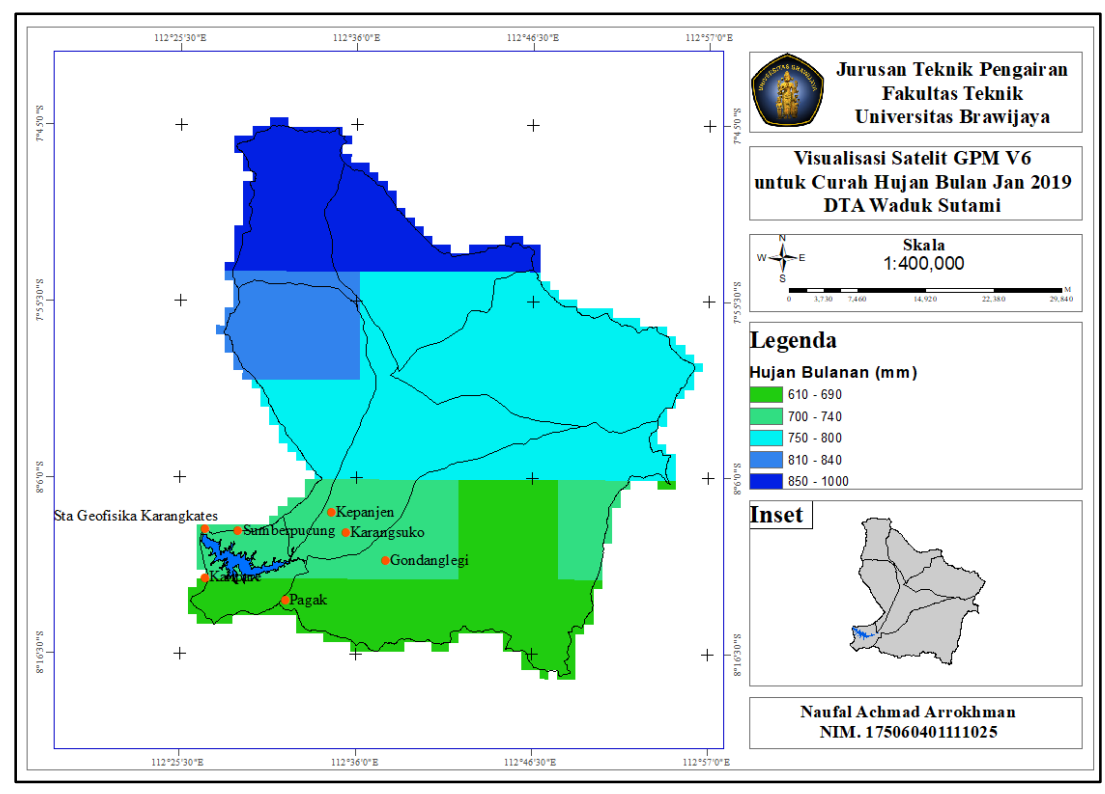

Gambar 2: Visualisasi satelit terpilih di daerah tangkapan air Waduk Sutami pada Januari 2019 (Satelit Curah Hujan GPM V6) 


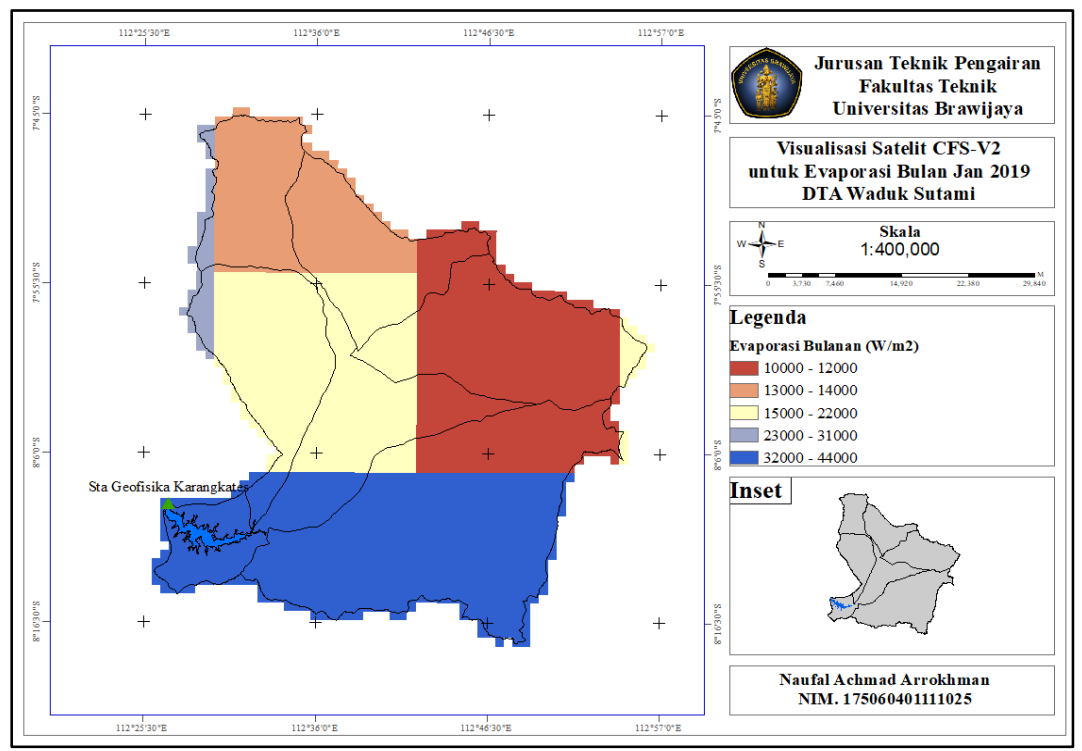

Gambar 3: Visualisasi satelit terpilih di daerah tangkapan air Waduk Sutami pada Januari 2019 (Satelit Evaporasi CFS-V2)

Gambar 2 merupakan bentuk visualisasi dari satelit curah hujan dan evaporasi terpilih yang direkam pada Bulan Januari 2019. Data diperoleh melalui Google Earth Engine (GEE) lalu diolah menggunakan perangkat lunak ArcGIS 10.4. Dari gambar tersebut dapat terlihat ukuran resolusi spasial pada GPM V6 sebesar $0,1^{0}(11,11 \mathrm{~km})$ dan CFS-V2 sebesar $0,2^{0}(22,20 \mathrm{~km})$. Data satelit curah hujan dan evaporasi dikoreksi menggunakan persamaan pada Tabel 8. Khusus data satelit evaporasi perlu dikonversi dari satuan $\mathrm{W} / \mathrm{m}^{2}$ menjadi $\mathrm{mm}$. Untuk mengonversi $\mathrm{W} / \mathrm{m}^{2}$ menjadi $\mathrm{mm} /$ hari perlu dikalikan dengan faktor 0,0353 [8].

Pada Bulan Januari 2019 di Daerah Tangkapan Air (DTA) Waduk Sutami memiliki curah hujan tertinggi pada area Brantas Hulu, sedangkan pada area Waduk Sutami cenderung rendah. Hal ini berbanding terbalik dengan evaporasi yang menunjukkan nilai tertinggi pada area Waduk Sutami, sedangkan pada area Brantas Hulu bernilai rendah.

\section{Kesimpulan}

Berdasarkan hasil analisis studi dapat disimpulkan bahwa satelit curah hujan TRMM 3B42, CHIRPS, dan GPM V6 periode bulanan memiliki hasil validasi yang berbeda-beda. Hasil evaluasi menunjukkan hasil validasi terbaik satelit TRMM 3B42 dengan nilai RMSE, NSE, R, dan KR berturut-turut sebesar 45,419; 0,858; 0,931; 0,724\%. Hasil validasi terbaik satelit CHIRPS dengan nilai RMSE, NSE, R, dan KR berturut-turut sebesar 49,785; 0,864; 0,958; 0,464\%. Hasil validasi terbaik satelit GPM V6 dengan nilai RMSE, NSE, R, dan KR berturut-turut sebesar 48,$281 ; 0,869 ; 0,944 ; 0,677 \%$.

Satelit evaporasi GLDAS-2.1 dan CFS-V2 juga memiliki hasil validasi yang berbedabeda. Hasil evaluasi menunjukkan hasil validasi terbaik satelit GLDAS-2.1 dengan nilai RMSE, NSE, R, dan KR berturut-turut sebesar 9,187; 0,684; 0,844; 0,842\%. Hasil validasi terbaik satelit CFS-V2 dengan nilai RMSE, NSE, R, dan KR berturut-turut sebesar 4,976; 0,$909 ; 0,968 ; 1,174 \%$.

Pada intinya, seluruh satelit curah hujan (TRMM 3B42, CHIRPS, dan GPM V6) maupun satelit evaporasi (GLDAS-2.1 dan CFS-V2) dapat digunakan sebagai alternatif 
data hidrologi di Kawasan Waduk Sutami. Hanya saja satelit curah hujan GPM V6 dan satelit evaporasi CFS-V2 memiliki tingkat keakurasian yang lebih tinggi dan performa yang lebih baik berdasarkan simulasi kalibrasi dan validasi.

\section{Ucapan Terima Kasih}

Terima kasih kepada Dinas PU Sumber Daya Air Kabupaten Malang dan Stasiun Geofisika Karangkates atas kemudahan dalam pemberian akses data curah hujan dari 7 (tujuh) stasiun hujan dan data evaporasi dari tahun 2001-2019.

\section{Daftar Pustaka}

[1] L. M. Limantara, Rekayasa Hidrologi-Edisi Revisi. Yogyakarta: ANDI, 2018.

[2] D. W. Pratiwi, J. Sujono, and A. P. Rahardjo, "Evaluasi Data Hujan Satelit untuk Prediksi Data Hujan Pengamatan Menggunakan Cross Correlation," Semin. Nas. Sains dan Teknol., no. November, pp. 1-11, 2017.

[3] A. Faisol, Indarto, E. Novita, and Budiyono, "Komparasi Antara Climate Hazards Group Infrared Precipitation With Stations (CHIRPS) Dan Global Precipitation Measurement (GPM) dalam Membangkitkan Informasi Curah Hujan Harian di Provinsi Jawa Timur," J. Teknol. Pertan. ANDALAS, vol. 24, no. 2, pp. 148-156, 2019.

[4] M. D. Syaifullah, "Validasi Data TRMM Terhadap Data Curah Hujan Aktual di Tiga DAS di Indonesia," J. Meteorol. dan Geofis., vol. 15, no. 2, pp. 109-118, 2014 , doi: 10.31172/jmg.v15i2.180.

[5] E. Mulyandari and H. Susila, "Validasi Data Curah Hujan Satelit TRMM dan PERSIANN dalam Analisis Debit Banjir Rencana di DAS Telaga Lebur," J. Tek. Sipil dan Arsit., vol. 25, no. 2, pp. 16-22, 2020, doi: 10.36728/jtsa.v25i2.1070.

[6] J. M. Ginting, J. Sujono, and R. Jayadi, "Analisis Hubungan Data Hujan Satelit dengan Hujan Terukur ARR Kalibawang," Pros. Konf. Pascasarj. Tek. Sipil, no. November, pp. 89-102, 2019.

[7] Soewarno, KLIMATOLOGI; Pengukuran dan Pengolahan Data Curah Hujan, Contoh Aplikasi Hidrologi Dalam Pengelolaan Sumber Daya Air. Yogyakarta: Graha Ilmu, 2015.

[8] M. G. Bos, R. A. L. Kselik, R. G. Allen, and D. J. Molden, Water requirements for irrigation and the environment, vol. 9781402089. 2009.

[9] Soewarno, Hidrologi Aplikasi Metode Statistik untuk Analisa Data Jilid 1. Bandung: Nova, 1995.

[10] Indarto, Hidrologi Dasar Teori dan Contoh Aplikasi Model Hidrologi. Jakarta: Bumi Aksara, 2012.

[11] S. Lufi, S. Ery, and R. Rispiningtati, "Hydrological Analysis of TRMM (Tropical Rainfall Measuring Mission) Data in Lesti Sub Watershed," Civ. Environ. Sci., vol. 003, no. 01, pp. 018-030, 2020, doi: 10.21776/ub.civense.2020.00301.3. 